$\xi^{2}=1$ 줄

\title{
Hydrogeological appraisal of basement and sedimentary terrain in Ogun state using Geoelectrical methods
}

\author{
Aladeboyeje Adegoke Ige ${ }^{1}$, Coker Joseph Olakunle ${ }^{2}$, Agbasi Okechukwu Ebuka ${ }^{3 *}$, Inyang Namdie Joseph ${ }^{3}$ \\ ${ }^{1}$ Department of Physical Sciences, Ondo State University of Science and Technology, Okitipupa, Nigeria \\ ${ }^{2}$ Department of Physics, Olabisi Onabanjo University, Ago-Iwoye, Nigeria \\ ${ }^{3}$ Department of Physics, Michael Okpara University of Agriculture, Umudike, Nigeria \\ ${ }^{4}$ Department of Physics, University of Uyo, Uyo, Nigeria \\ *Corresponding author E-mail: agbasi.okechukwu@gmail.com
}

\begin{abstract}
The coverage of the groundwater potential was estimated using the geometry calculator, the potential groundwater zones were validated using geophysical surveyed points of some selected locations in Abeokuta and Ewekoro. Generally, the result of the study shows that the higher the aquifer thickness and depth the better the groundwater potential. In the basement part of the study area (Abeokuta), the Northwestern region is characterized by increase in overburden thickness (28.1 m at VES-9), weathered layer resistivity (546 $\Omega \mathrm{m}$ at VES-7) and longitudinal conductance unit (0.193 S at VES-3 and 0.218 S at VES-7), reflecting high aquifer potentials. In this regard, the Northeastern part of the study area can be categorized as good groundwater potential; moving towards the Southwestern part from the northern, groundwater potentiality changes from good to moderate while the Southwestern/ central part is categorized as area with poor groundwater potential. In the Sedimentary part of the study area (Ewekoro), the northcentral region is characterized by increase in overburden thickness (93 $\mathrm{m}$ at VES-10), longitudinal conductance unit (3.644 S at VES-6), reflecting high aquifer potentials. In this regard, the northcentral part of the study area can be categorized as good groundwater potential; moving towards the northeastern part of the study area, groundwater potentiality changes from good to moderate while the southwestern part is categorized as area with poor groundwater potential. The area showed very good protective capacity at VES's $2,3,4,5,7$ and 8 ; making $60 \%$ of the VES stations. Good protective capacity is observed at VES 1 and 6, making 15\% of the VES stations in the town. The excellent protective capacity is observed at VES 9 and 10 ; making $15 \%$ of the study area.
\end{abstract}

Keywords: Groundwater Potential; Hydraulic Conductivity; Transmissivity; Longitudinal Conductance.

\section{Introduction}

Groundwater as a component of the hydrologic cycle is the water that is found underneath the earth's surface where all the pore spaces in the soil, sediments or rocks are completely stacked with water. Groundwater originates from precipitation and it is transported to aquifers through the process of infiltration. The rate at which water infiltrates is affected by several factors such as slope, lithology, rainfall, land use/ cover, and drainage pattern. Flat terrains enhance infiltration rate and lead to increased ground water storage potential (Bruijnzeel, 2004).

Water is drained down the earth by gravity until an impermeable rock or soil is reached. The water begins to accumulate above the layer immediately above the impermeable material. In this zone, water fills all the accessible pore spaces here (Okechukwu \& Sunday, 2016). The phreatic zone may extend to considerable depth, but as the depth increases the weight of overburden tends to close the pore space little water is found at depths greater than $3 \mathrm{~km}$ (Montgomery, 1990). Above the phreatic zone is a zone (unsaturated zone or the vadose zone) that is composed of rocks in which the pore spaces are partly filled with water and air. Hence it is also called zone of aeration. Groundwater therefore represents the water in the zone of saturation (phreatic zone) and below the water table. Water table is the top of the zone of saturation where the saturated zone is not confined by overlying impermeable rocks.

The movement of groundwater in the subsurface is quite complex, but in simple terms it can be described as being driven by potential energy. At any point in the saturated subsurface, groundwater has a hydraulic head value that describes its potential energy, which is the combination of its elevation and pressure. In an unconfined aquifer, the water table elevation represents the hydraulic head, while in a confined aquifer the potentiometric surface represents the hydraulic head. Water moves in response to the difference in hydraulic head from the point of highest energy toward the lowest.

Badmus \& Olatinsu (2010) carried out a geophysical survey in Federal College of Education, Osiele, Abeokuta, southwestern which falls within the basement complex of Nigeria, to examine the aquifer characteristics and groundwater recharge pattern in the study area. Ariyo \& Adeyemi (2012) carried a geophysical assessment in Ishara Ogun state Southwestern Nigeria to determine groundwater occurrence and aquifer characteristics within the area. Odunaike, et al., (2013) used vertical electrical resistivity to explore groundwater at Remo North Local Government which falls within the sedimentary terrain of Nigeria. Salami \& Olorunfemi (2014) carried out a geophysical survey to evaluate groundwater potential in Abeokuta Ogun state which falls within the basement complex of Nigeria. Coker et al., 
(2016) investigated groundwater potentials of Oke - Badan Estate, Ibadan, Southwestern Nigeria. Fashae et al., (2014) delineated groundwater potential zones in crystalline basement terrain of Southwestern Nigeria.

\section{Geology of the study area}

The study area is Abeokuta and Ewekoro within the Ogun river basin, Southwestern Nigeria. Abeokuta is one of the most prominent urban settlements in the South-western Nigeria. The gneiss-migmatite complex is the most widespread rock formation within the study area. It comprises gneisses, quartzite, calcsilicate, biotite-hornblende schist and amphibolites (Rahaman, 1976). The older granites and around the Abeokuta, are of late Precambrian to early Palaeozoic in age and are magmatic in the origin (Jones \& Hockey, 1964). Abeokuta falls within the basement complex of the geological setting of south-western Nigeria (Figure 1). The basement complex rocks of Pre-Cambrian age are made up of older and younger granites, with the younger and older sedimentary rocks of the both tertiary and secondary ages. The area is underlain by basement rocks, which cover about $40 \%$ of landmass in Nigeria (Obaje, 2009).

Ewekoro formation belongs to tertiary-formed Palaeocene and Eocene; and the greater part of the depression is a potential artesian basin where ground water can be sourced. Adegoke et al., (1976) outlined the Albran and younger Palaeographic history of Nigeria and summarized the nature and extent of transgressive, regressive phases as well as the nature of the sediment. The geology of Ogun State comprises sedimentary and basement complex rocks, which underlie the remaining surface area of the state. It also consists of intercalations of argillaceous sediment. The rock is soft and friable but in some places cement by ferruginous and siliceous materials. The sedimentary rock of Ogun State consists of Abeokuta formation lying directly above the basement complex (Figure 1). Ewekoro, Oshosun and Ilaro formations in turn overlie this, which are all overlain by the coastal plain sands (Benin formation).

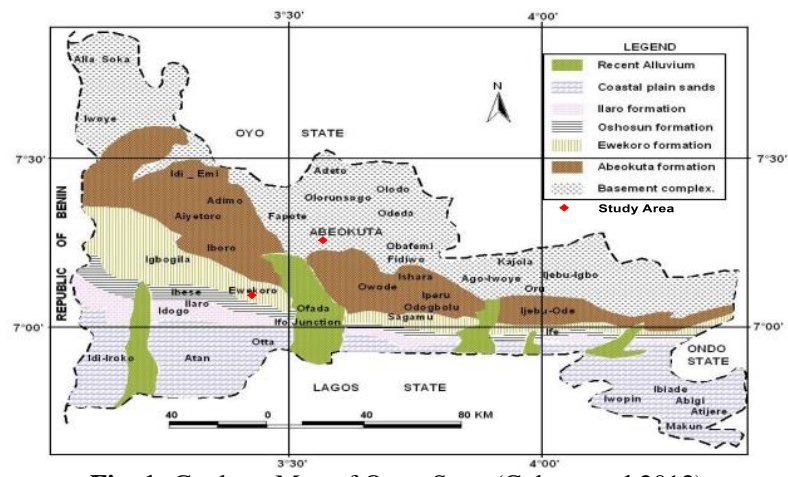

Fig. 1: Geology Map of Ogun State (Coker, et al 2013).

\section{Methodology}

The geophysical investigations made use of the resistivity method comprising mainly of Vertical Electrical Sounding (VES) at various strategically located and potentially anomalous points in the area under survey. Vertical electrical sounding investigates the way in which the resistivity of the ground varies with depth and is often related to strength and conductivity of the formation. The period for the investigation was April 2017, when the ground was considerably moist. This ensured good current conduction between the earth and the electrodes. The electrical resistivity measurements were taken along approximately straight roads and footpaths (Figure 2).

The data obtained were subjected to both manual and computer interpretation. The manual interpretation was done with log-log sheet and a master curve sheet to obtain an apparent resistivity curve. The computer interpretation was done using WINRESIST computer software. The program is designed to process sounding data and it is built around three main procedures which are smoothing or filtering of noisy field data, computation of apparent resistivity models and inversion of the data in an iterative procedure. The interpreted data was presented in form of VES curves and geoelectric sections.
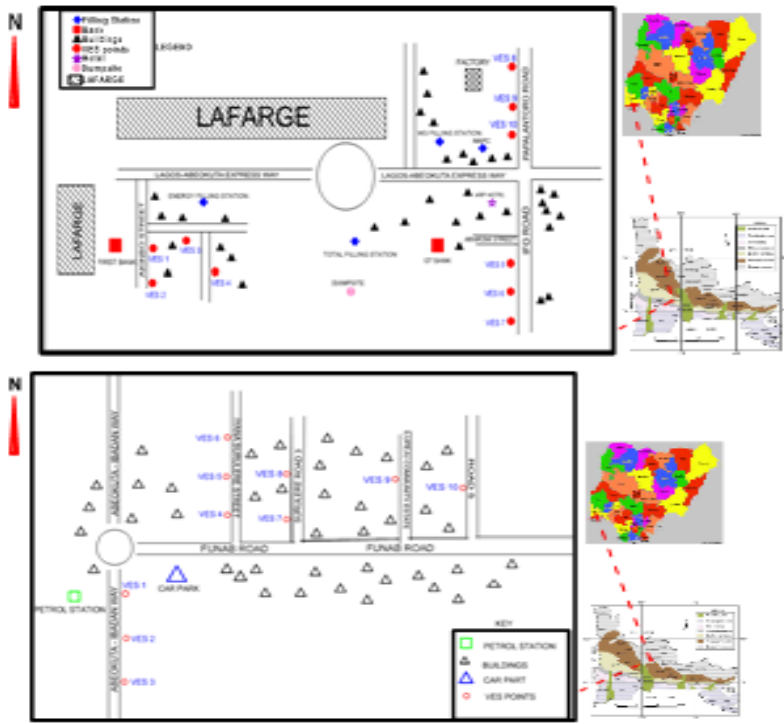

Fig. 2: Location Map of Ewekoro and Abeokuta Showing VES Points. 


\subsection{Geoelectric (dar-zarrouk) parameters}

A geoelectric layer is described by two fundamental parameters: its resistivity $\left(\rho_{i}\right)$ and thickness $\left(h_{i}\right)$ where the subscript indicates the position of the layer in the section. Other geoelectric parameters can be derived from its resistivity and thickness. For a sequence of $n$ horizontal stratified, homogeneous and isotropic layered earth model of resistivity $\rho_{i}$ and thickness $h_{i}$, the combinations of the layer parameters $\left(\rho_{\mathrm{i}}\right.$ and $\left.\mathrm{h}_{\mathrm{i}}\right)$ can be presented as

$$
S_{i}=\sum_{i=1}^{n} \frac{h_{i}}{\rho_{i}}
$$

And

$$
\mathrm{T}_{\mathrm{i}}=\sum_{\mathrm{i}=1}^{\mathrm{n}} \rho_{\mathrm{i}} \times \mathrm{h}_{\mathrm{i}}
$$

Where $S_{i}$ and $T_{i}$ represent longitudinal conductance (mhos) and transverse resistance $\left(\Omega \mathrm{m}^{2}\right)$ respectively. The combined resistance and thickness of earth layers was necessary because it checks some limitations, such as: heterogeneities effects, topographic effect and assumptions that beddings are horizontal associated with VES data interpretation (Thomas et al., 2018). The longitudinal resistivity ( $\rho_{\mathrm{L}}$ ), transverse resistivity $\left(\rho_{\mathrm{T}}\right)$ and anisotropy $(\lambda)$ were determined using equations $(3,4$ and 5 respectively). All these were necessary to reduce ambiguities related to VES interpretation, which are mainly produced by principles of equivalence and suppression and cause intermixing in identifying depth limits for the electrical zones during interpretation.

$$
\begin{aligned}
& \rho_{\mathrm{L}}=\frac{\mathrm{H}_{\mathrm{i}}}{\mathrm{S}_{\mathrm{i}}} \\
& \rho_{\mathrm{T}}=\frac{\mathrm{T}_{\mathrm{i}}}{\mathrm{H}_{\mathrm{i}}} \\
& \lambda_{\mathrm{i}}=\left(\frac{\rho_{\mathrm{T}}}{\rho_{\mathrm{L}}}\right)^{1 / 2}
\end{aligned}
$$

Dar-Zarrouk geoelectrical parameters deduced for the study areas were used to characterize aquifers, delineate the groundwater potential zones and estimate the aquifer protective capacity. Contour maps for longitudinal conductance $(\mathrm{S})$, transverse resistance $(\mathrm{T})$, transverse resistivity $(\rho t)$, longitudinal resistivity $(\rho \mathrm{l})$, and anisotropy $(\lambda)$ were constructed (Okechukwu et al., 2019).

\section{Results and discussion}

In this work, a total of 20 VES points was probed and this covers two locations, Abeokuta (Basement complex) and Ewekoro (Sedimentary terrain) within Ogun river basin, Southwestern Nigeria. The result of the vertical electrical sounding obtained showed the different layers with their resistivities and depths for both study area. The interpreted results were used to delineate the layers with varying curve types which is a reflection of lithological variation with depth. Also, Dar-Zarrouk parameters (longitudinal conductance, transverse resistance, longitudinal resistivity, transverse resistivity and electric anisotropy) were derived from the interpreted results. The results showed three-layered, four-layered and five-layered types of VES curves for Abeokuta and Ewekoro respectively. In Abeokuta, the curve types obtained for the three-layered type is $\mathrm{H}$, for the four-layered type is $\mathrm{KH}$ while for five layered type is $\mathrm{HKH}$. For Ewekoro, the curve types obtained for three-layered type is $\mathrm{H}$, for four-layered type are $\mathrm{KH}$ and $\mathrm{QH}$ while for five layered type, we have $\mathrm{KQH}$ and QHA.

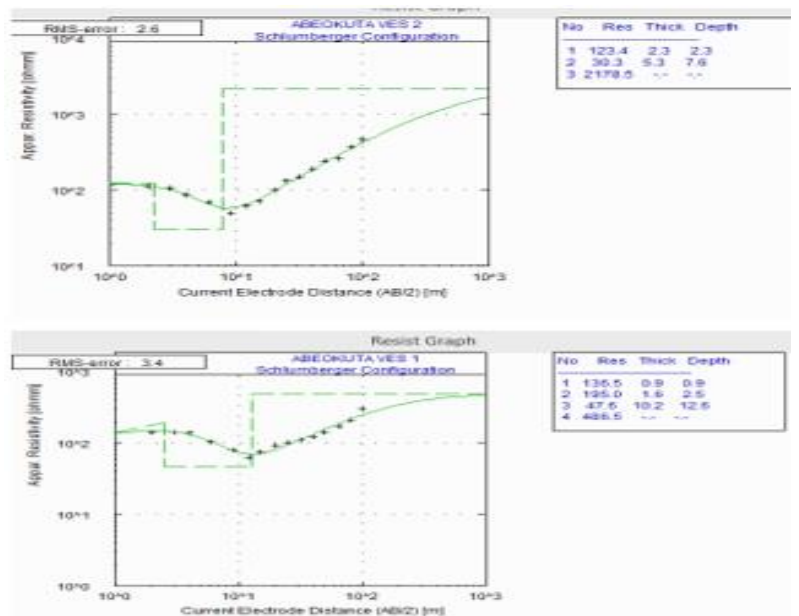

Fig. 3: Sounding Curves.

\subsection{Isopach maps}

The overburden thickness is the sum total of the thickness of the layers that is above the bedrock in a given location. Overburden thickness is important in hydrogeological investigation as it shows the distances of layers that is above the aquifer and groundwater has been observed to be present in areas which have a considerable overburden thickness (Coker et al., 2013). The Isopach maps for overburden thickness as depicted in figures $4 \mathrm{a}$ and $4 \mathrm{~b}$ show Abeokuta to have very high thickness values at the northwest and lowest at southeast. 
However, a peak is observed at the southwest and plunges deeply towards the central. Ewekoro has high thickness at the northeastern part and lowest at the south.

Aquifer thickness is the thickness of the layer that bears sufficient amount of groundwater in a given location. It is however expected that the groundwater yield is proportional to the thickness of the aquiferous layer. Hence, the higher the thickness of the aquifer, the more its capacity to bear groundwater. Abeokuta has high aquifer thickness at the southeastern part and slightly high at the central western part. It is lowest at the northwestern part. Ewekoro has very high aquifer thickness at the northwestern and lowest at the south and rising slightly towards the central. This is shown in figures $5 \mathrm{a}$ and $5 \mathrm{~b}$.
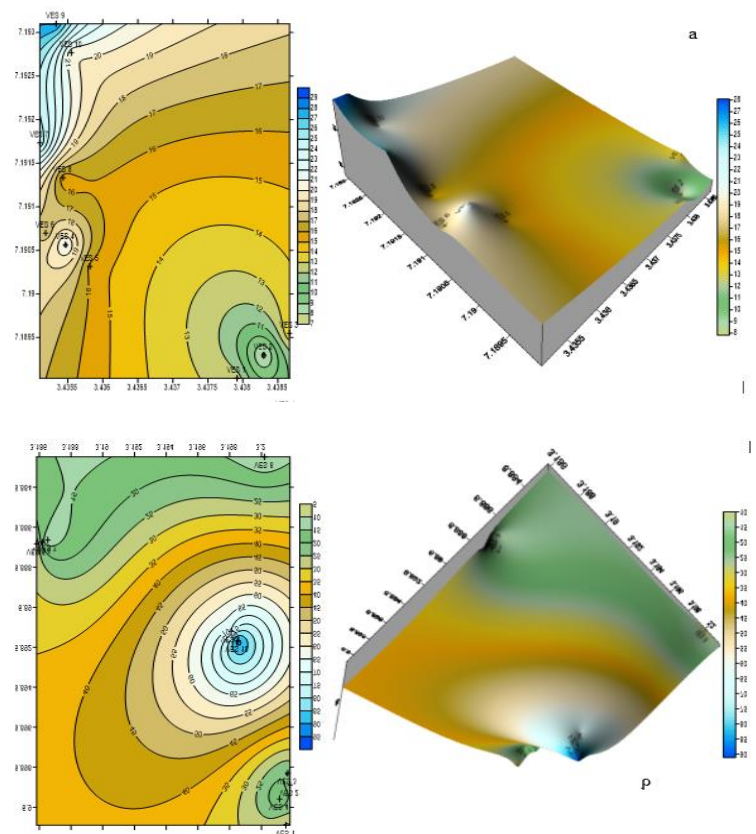

Fig. 4: Maps of Overburden Thickness for (A) Abeokuta and (B) Ewekoro.
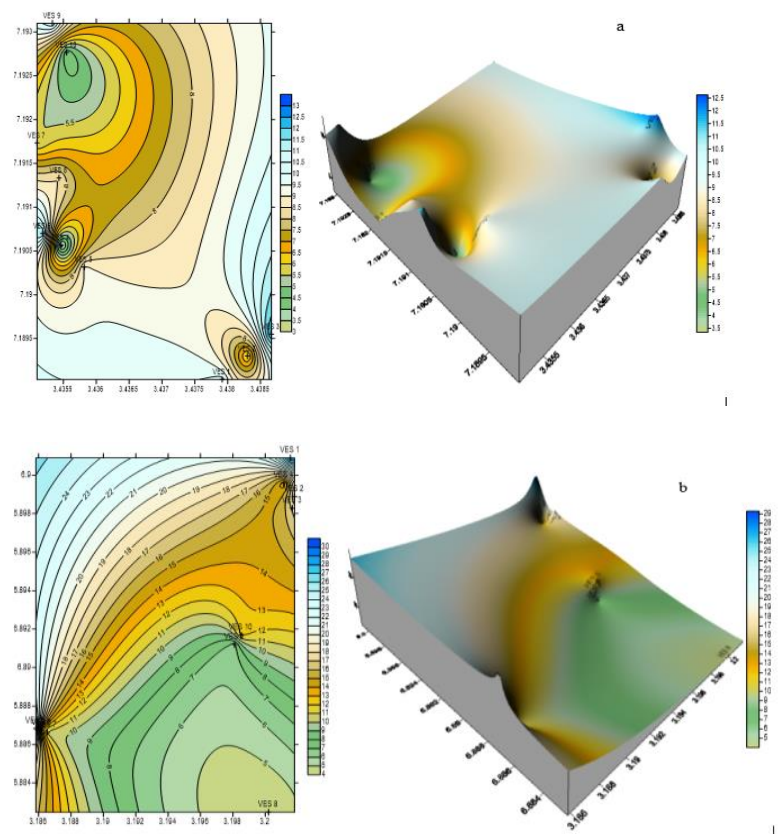

Fig. 5: Maps of Aquifer Thickness for (A) Abeokuta and (B) Ewekoro.

\subsection{Isoresistivity maps}

Abeokuta has a basement resistivity that is generally low and lowest at north central part of the study area. It is highest at the southeast. Ewekoro too has generally low basement resistivity but very high at the southwestern edge. This is as depicted in figures $6 a$ and $6 b$ respectively.

The isoresistivity map of the layer considered as the main aquifer in the area is depicted in figures 7a and 7b. Abeokuta has generally low resistivity for the weathered layer but high at the northwestern end while generally low at southern end. Ewekoro records high at the central part of northeastern part and very low towards the southwestern edge. 

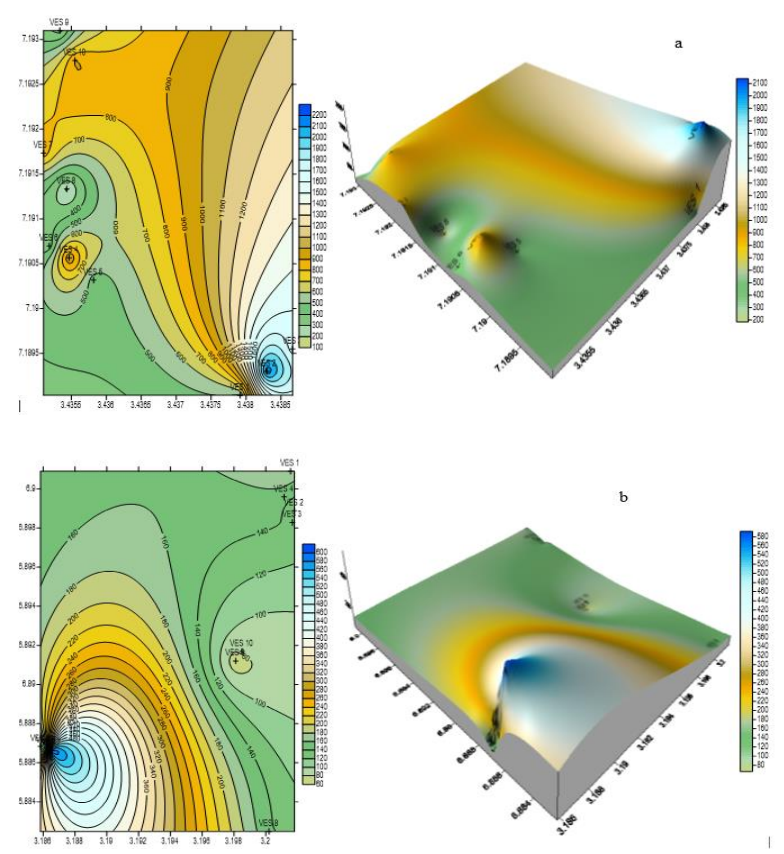

Fig. 6: Isoresistivity Maps of Basement Layer for (A) Abeokuta and (B) Ewekoro.
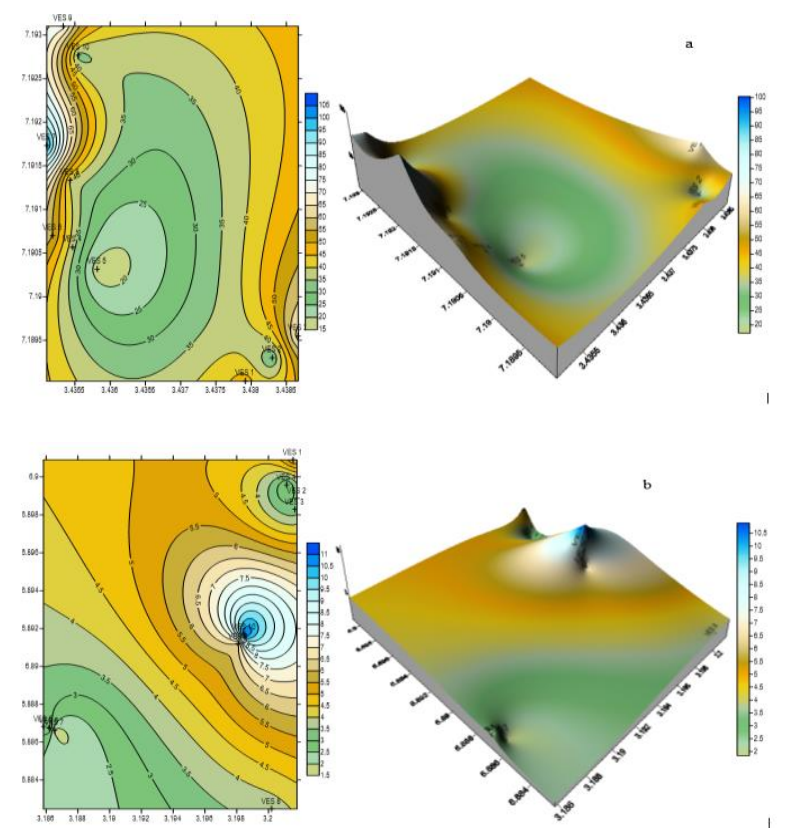

Fig. 7: Isoresistivity Maps of Weathered Layer for (A) Abeokuta and (B) Ewekoro.

\subsection{Groundwater potential evaluation}

The resistivity of the basement cannot be solely relied on to identify areas of promising aquifers (Olayinka, et al, 2004). Hence, the groundwater potential evaluation of the areas was based on the integration of the aquifer resistivity, aquifer thickness, overburden thickness and longitudinal conductance maps. The groundwater prolific area will have high accumulation of current density, which reflects the presence of fracture zones (Sharma \& Baranwal 2005), thickness overburden greater than $10 \mathrm{~m}$ (Olayinka et. al., 2004) and aquifer resistivity ranging from $100 \Omega \mathrm{m}$ to $800 \Omega \mathrm{m}$ (Adiat et. al., 2004). In addition, groundwater potential area should have low longitudinal conductance unit, which indicate an increase in transmissivity (Kithiia, 2012).

In the basement part of the study area (Abeokuta), the Northwestern region is characterized by increase in overburden thickness ( $28.1 \mathrm{~m}$ at VES-9), weathered layer resistivity ( $546 \Omega \mathrm{m}$ at VES-7) and longitudinal conductance unit (0.193 S at VES-3 and 0.218 S at VES-7), reflecting high aquifer potentials. In this regard, the Northwestern part of the study area can be categorized as good groundwater potential; moving towards the Southwestern, groundwater potentiality changes from good to moderate while the Southwestern/ central part is categorized as area with poor groundwater potential

In the Sedimentary part of the study area (Ewekoro), the northcentral region is characterized by increase in overburden thickness (93 $\mathrm{m}$ at VES-10), longitudinal conductance unit (3.644 S at VES-6), reflecting high aquifer potentials. In this regard, the northcentral part of the study area can be categorized as good groundwater potential; moving towards the northeastern part of the study area, groundwater potentiality changes from good to moderate while the southwestern part is categorized as area with poor groundwater potential.

\subsection{Groundwater protective capacity}


Resistivity and layer thickness were used to compute the longitudinal conductance of layers. High longitudinal conductance indicated relatively high protective capacity. The protective capacity provides information for more vulnerable zones which help to protect groundwater resources and also to evaluate the potential for water quality improvement.

Longitudinal conductance ranged between 0.193 mhos in VES 3 to 0.655 mhos (VES 5) in Abeokuta as shown in figure 8a. The weak protective capacity is observed only at VES 3 . The rest (VES 1, 2, 4, 5, 6, 7, 8, 9 and 10) of the VES stations in the area have moderate protective capacity constituting about $90 \%$ of the area. None of the VES stations in the area proved to have good protective capacity. In Ewekoro, longitudinal conductance ranged between 3.644mhos in VES 6 to 10.391mhos (VES 10) as shown in figure 8b. The area showed very good protective capacity at VES's 2, 3, 4, 5, 7 and 8; making $60 \%$ of the VES stations. Good protective capacity is observed at VES 1 and 6, making 15\% of the VES stations in the town. The excellent protective capacity is observed at VES 9 and 10 ; making $15 \%$ of the study area.

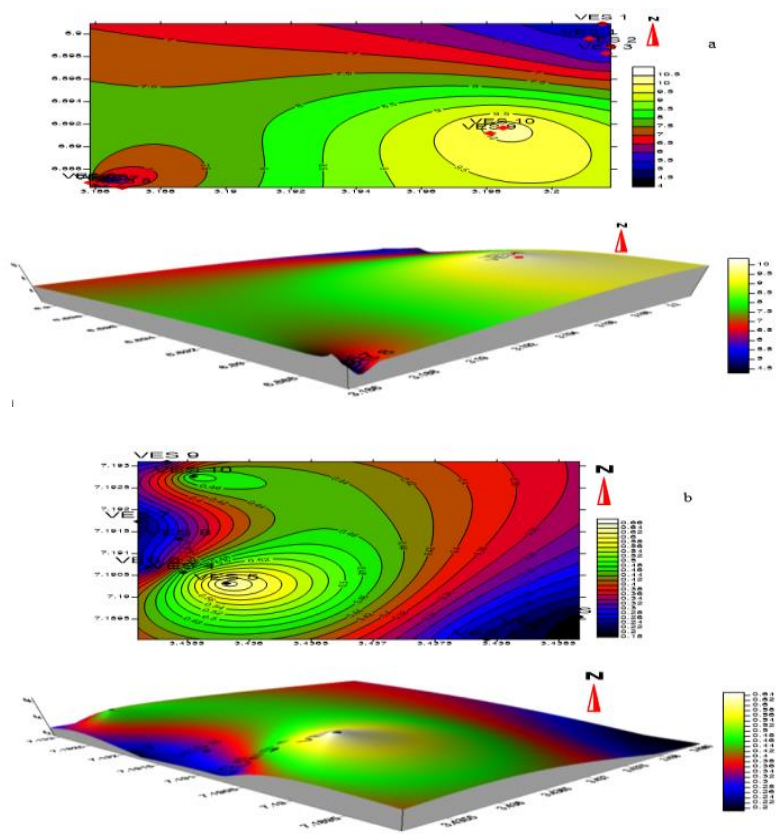

Fig. 8: Longitudinal Conductance Map (A) Abeokuta and (B) Ewekoro.

\section{Conclusion}

The groundwater potential zones have been derived for the entire Ogun drainage basin and it has been divided into mainly four categories namely high, moderate, low and very low potentials. It was observed from the study that high groundwater potential zones are located in the northern and central parts of the study area. However, the study shows that there is a relationship between the vertical electrical sounding (VES). This study has shown that there is large spatial variability of groundwater potentiality within the study area. The variability closely followed variability in the lithology of the study area. This study generally shows that groundwater potentiality increases with an increase in the thickness of aquifer.

\section{Availability of data and material}

All data and materials used in this work are found within the manuscript

\section{Competing interests}

The authors of the manuscript titled "Hydrogeological Appraisal of Basement and Sedimentary Terrain in Ogun State Using Geoelectrical Methods" that there is no conflict of interest between the authors and/or any organization.

\section{Funding}

All funding for this research work was self-sponsored by the authors without any external funding

\section{Acknowledgements}

We the authors acknowledge all the universities where the authors of this research emanated from

\section{References}

[1] Bruijnzeel, L.A. (2004). Hydrological functions of tropical forests: Not Seeing the Soil for Trees. Agriculture, ecosystems and environment. 104(1), 185-228. https://doi.org/10.1016/j.agee.2004.01.015.

[2] Okechukwu E.A. \& Sunday E.E. (2016) Hydro-Geoelectric Study of Aquifer Potential in Parts of Ikot Abasi Local Government Area, Akwa Ibom State, Using Electrical Resistivity Soundings. International Journal of Geology and Earth Sciences. 2(4): $43-54$. 
[3] Montgomery, C. W. (1990). Physical Geology 2nd edition. Wm. C. Brown Publishers United States of America.

[4] Badmus, B.S. \& Olatinsu, O.B. (2010). Aquifer characteristics and groundwater recharge pattern in a typical basement complex, Southwestern Nigeria. African Journal of Environmental Science and Technology, 4(6), 328-342. https://doi.org/10.5897/AJEST09.214

[5] Ariyo, S.O. \& Adeyemi, G.O. (2012). Geoelectrical characterization of aquifers in the basement complex/sedimentary transition zone, southwestern. Nigerian. International Journal of Geology and Mining Research, 3(3), 54-62.

[6] Odunaike, R.K., Akinyemi, L.P., Oyekunle, A. \& Ijeoma,G.C. (2013). Application of Vertical Electrical Method in Groundwater Exploration at Remo North Local Government in Ogun State of Nigeria. Journal of Emerging Trends in Engineering and Applied Sciences (JETEAS), 4(4), 672678.

[7] Salami, B.M. \& Olorunfemi, M.O. (2014). Hydrogeophysical evaluation of the groundwater potential of the central part of Ogun state, Nigeria. Ife journal of science advanced scientific research and technology.

[8] Coker, J.O. Makinde V., \& Olowofela J.A. (2016) Geophysical Investigation of Groundwater potentials of Oke-Badan Estate, Ibadan, Southwestern Nigeria. Nigerian Institute of Physics Journal 26, 124-134.

[9] Fashae, A., Moshood, N., Talabi, A.O. \& Adedeji O.I. (2014). Delineation of groundwater potential zones in the crystalline basement terrain of southwest Nigeria: An integrated GIS and Remote Sensing approach. Appl Water Sci. 14, 19-38. https://doi.org/10.1007/s13201-013-0127-9.

[10] Rahaman, M.A. (1976). A Review of the Basement Geology of South Western Nigeria. In: Geology of Nigeria, Kogbe, C.A. (Ed.). Elizabethan Publishing, Surulere, Lagos State, Nigeria, 41-58.

[11] Jones, H.A. \& Hockey, R.D. (1964). The geology of parts of south western Nigeria. Bull. Geological Survey Nigeria, 31, 101

[12] Obaje, N.G., (2009). Geology and Mineral Resources of Nigeria. Springer, Berlin, Germany, 221pp. https://doi.org/10.1007/978-3-540-926856.

[13] Adegoke, O.S., Ogbe, F.G.A. \& Jan Du Chene, R.E. (1976). Excursion to the Ewekoro quarry (Paleocene-Eocene). Geol. Guide Nigerian Cretaceous-Recent Loc. 1-17.

[14] Thomas A.H., Fidelis A.U. \& Okechukwu E.A. (2018). Hydraulic and Geoelectric relationships of Aquifers Using Vertical Electrical Sounding (VES) in parts of Obudu, Southern Nigeria. World Scientific News. 94(2) $261-275$.

[15] Okechukwu E.A., Nadia A.A., Zaidoon T.A., \& Sunday E.E. (2019). Integrated geophysical data and GIS technique to forecast the potential groundwater locations in part of South Eastern Nigeria. Iraqi Journal of Science. 60(5) 1013 - 1022.

[16] Coker, J.O., Makinde, V., Adesodun, J.K. \& Mustapha, A.O. (2013). Integration of Geophysical and Geotechnical Investigation for a proposed New Lecture Theatre at Federal University of Agriculture, Abeokuta, South Western Nigeria. International Journal of Emerging Trends in Engineering and Development. 5: 338-348.

[17] Olayinka, A.I., Amidu, S.A. \& Oladunjoye, M.A. (2004). Use of electromagnetic profiling and sounding for groundwater exploration in the crystalline basement of Igbeti, Southwestern Nigeria. Global Journal of Geological Science, 2(2) 243-253. https://doi.org/10.4314/gigs.v2i2.18701.

[18] Sharma, S.P. \& Baranwal, V.C. (2005). Delineation of groundwater-bearing fracture zones in a hard rock area integrating very low frequency electromagnetic and resistivity data. Journal of Applied Geophysics. 57, 155-166. https://doi.org/10.1016/1.jappgeo.2004.10.003.

[19] Adiat, K.A.N., Nawawi, M.N.M. \& Abdullah, K. (2012). Assessing the Accuracy Of GIS-Based Elementary Multi-Criteria Decision Analysis as Spatial Prediction Tool: a case of predicting potential zones of sustainable groundwater resources. Journal of Hydrology, 440-441, 75-89. https://doi.org/10.1016/j.jhydrol.2012.03.028.

[20] Kithiia, S.M. (2012). Integrated Water Resources Management in the wake of Climate Change scenario in Kenya. Unpulished doctoral dissertation, University of Nairobi. 